\title{
PERSPECTIVE OF MEDIATION EFFECTIVENESS THEORY AS MAIN OPTIONS IN ORDER TO LOWER DIVORCE RATE
}

\author{
Masrur Ridwan \\ Sultan Agung Islamic University \\ masrurridwan4@gmail.com \\ Aryani Witasari \\ Sultan Agung Islamic University \\ aryani@unissula.ac.id \\ Ahmad Hadi Prayitno \\ Sultan Agung Islamic University \\ prayitnolwf@gmail.com
}

\begin{abstract}
The purpose of this paper is to examine mediation as a way effective to reduce the divorce rate and the obstacles and challenges that create mediation as the means chosen to reduce the divorce rate in Indonesia. The increase and decrease in claimable divorce rates can basically be monitored, if supported by various parties, including through the implementation of effective mediation and efficient. In general, the biggest cause of divorce in Indonesia is dispute continuous and economic problems. Socialization and counseling about coaching the sakinah family has been awarded by the authorities. There is an obligation to conduct mediation before entering the court's domain as regulated in Supreme Court Regulation No.1 of 2016 is still being carried out halfheartedly tends to be mere formality. This is one of the obstacles in the difficulty there is an agreement in the mediation process. The divorce rate can be reduced significantly significant, if the parties involved in household cases have been pushed to take advantage of mediation institutions from an early age. The five elements according to effectiveness theory related to mediation as the main choice in suppressing the divorce rate well done.
\end{abstract}

Keywords: Divorce; Effectiveness; Mediation.

\section{A. INTRODUCTION}

Indonesia as a country with a population of 250 million and the majority of the age productive which means the age that is considered capable of getting married. From year after year, there are always problems in the world of marriage. Fight in the house stairs carried out by young couples always lead to divorce.

In a big city like Semarang every year it always increases, becomes one of the targets for stakeholders to reduce the divorce rate the. This is because in recent years, the divorce rate in mothers the provincial city covering an area of 373.8 square kilometers with a population of $1,668,578$ inhabitants (825,964 men and 842,614 women), from 2017 to 2019 relatively not decrease. If in 2017 the existing divorce lawsuit only reached 
3,253 cases, and in 2018 it rose to 3,534, then in 2019 (October data) cases which had been cut had reached 3,193. ${ }^{1}$

Existing data also show that the trend of divorce rates in the city dominated by inviolable divorce cases. In 2019, for example, out of 3,193 cases that had been was decided, 1,937 of which were litigation cases. ${ }^{2}$ That means the case Divorce in Semarang City mostly occurred on the initiative of the woman or wife. So far the court is still trying to take a peaceful path to suppressing the divorce rate in the city of Semarang. But the path of peace is pursued often hit a dead end because it collided on a complex problem between the two sides party.

The increase in the number of divorcees can actually be monitored, even reduced, if supported by various parties, among others, through the implementation of effective mediation and efficient. The cases that have already entered the court are considered insufficient effective, they even tend to be just a formality. Actually, the divorce rate can be suppressed significantly, if the parties involved in cases the household has been encouraged from an early age to take advantage of mediation institutions.

The development of Semarang City, which is now increasingly dynamic, can be seen, among others of the increase in inviolable divorce, which is about 70 percent, reversed with the divorce rate which is in the range of 30 percent. On the other hand, filing for divorce can actually be done considered decreased. ${ }^{3}$ Often times, conflicts between married couples appear to drag on, and require the assistance of others, form of mediation ${ }^{4}$ by a mediator ${ }^{5}$ or through court. How to resolve disputes outside the court humans have been familiar with them for a long time, and the way they take it is constantly evolving along with the progress of the times. If the dispute is resolved through a court process, it will always produce a winlose solution, that is in the end, it often creates new problems. If the dispute is resolved via out of court process, will result in a win-win solution . This is different from the litigation process in court which tends to produce new problems. ${ }^{6}$

The dispute resolution process outside the court has also long been known by Indonesian society. The various existing tribes resolve the dispute via deliberation to reach a consensus to make a decision. Batak tribe for example, solving problems through the "runggun adat forum", the Minang tribe uses "Peace judges institute", 7 and Javanese tribes use "village consultation". Islam too provide opportunities for adherents to resolve

1 Recap/report on divorce figures for the Semarang City Religious Court for 2017-2019

2 Ibid.,

3 Ibid.,

4 Mediation is a method of resolving disputes through the negotiation process to obtain agreement from the parties assisted by a Mediator (See Mahkamah Agung Regulation No.1/2016 Article 1 number 1 )

5 Dispute resolution without using a way to decide or force a settlement (See Mahkamah Agung Regulation No 1 of 2016 Article 1 point 2)

6 Frans Hendra Winata, Indonesian and International National Arbitration Dispute Resolution Law, Second Edition, Sinar Grafika, Jakarta, 2012, page. 9

7 Rika Lestari, Comparative Law of Dispute Resolution by Mediation at Courts and Outside Courts, Journal of Legal Studies, Volume 3 No. 2, 2013, page. 219 
disputes in a manner kinship through the intermediary of others who are neutral and impartial. ${ }^{8}$

In Indonesia, a concrete definition of mediation can be found in Article 1 Number 1 Regulation of the Supreme Court of the Republic of Indonesia Number 1 of 2016 which is stated, "mediation is a way of resolving disputes through the negotiation process to obtain an agreement between the parties, assisted by a mediator".

The definition of mediation is in Act No. 30 of 1999 concerning Arbitration and Alternative Dispute Resolution is regulated in Article 6 Paragraph (3) which reads: " ... in the case of a dispute or difference of opinion as referred to in paragraph (2) no can be resolved, then on the written agreement of the parties, dispute or difference income is completed through the help of one or more expert advisors as well through a mediator."

Mediation ${ }^{9}$ will bring the parties to agree to find outside solutions court, by conducting negotiations assisted by a third party neutral and impartial called the mediator. In this case the mediator must build positive interaction and communication, so that he is able to serve interests the parties, and try to offer alternatives in the fulfillment of interests the. ${ }^{10}$ More than that, the mediator must also be able to analyze and diagnose a particular dispute, and designing and controlling processes and interventions another with the aim of guiding the parties to reach a consensus. ${ }^{11}$ This way is sufficient good, fast, easy without being noticed by the other party as long as it is based on good faith. ${ }^{12}$ However at the practical level, the implementation of mediation is not as easy as it says.

\section{B. RESEARCH METHODS}

The approach method using normative juridical or legal research with a normative doctrinal approach, or normative juridical legal research or normative legal research is basically an activity that will examine internal aspects (to solve problems that exist in) positive law. ${ }^{13}$ On the one hand, the science of law with its original character as a normative science and on the other hand the science of law has empirical aspects. The empirical side is the study of empirical legal science such as sociological jurisprudence, and socio legal jurisprudence. Thus, from this point of view, normative

8 See the Qur'an, Surah Al-Hujurat verse 9 and Surah Annisa verse 114.

9 The mediation process here means mediation which must be carried out before the litigation process (based on Supreme Court Regulation No.1 of 2016).

10 Endrik Safudin, Alternative Dispute Resolution and Arbitration, Intans Publishing, Malang, 2018, page. 33-34.

11 Gary Goodpaster, Basic Economic Law Series 9: A Guide to Negotiation and Mediation, translated by Nogar Simanjuntak, Project ELIPS, Jakarta, 1999, page. 253-254.

12 Rudiyanti Dorotea Tobing, Aspects of Business Law: Definition, Principles, Theory and Practice, LaksBang Justitia, Surabaya, 2015, page. 305

13 Kornelius Benuf, Muhamad Azhar, Metodologi Penelitian Hukum sebagai Instrumen Mengurai Permasalahan Hukum Kontemporer, Jurnal Gema Keadilan, Volume 7 Edtion I, June 2020, page.20-33 
jurisprudence has a unique method of study. Empirical law can be studied through quantitative or qualitative research. ${ }^{14}$

\section{RESULT AND DISCUSSION}

\section{Mediation as the main option to reduce the internal divorce rate Dispute Resolution Theory perspective}

Hostilities or conflicts between husband and wife often appear to be protracted and for resolving these conflicts usually they need help from other parties, both assistance from family and outside parties. If the dispute has occurred cannot be resolved by the husband and wife's family the way that can be taken is to file a lawsuit in court. The verdict generated by the process This litigation is a win-lose solution, which in the end often creates problems new. If the dispute is resolved through an out of court process, it will result a win-win solution .

The public has long been familiar with the process of settling disputes outside the court Indonesia. Various tribes in Indonesia have also chosen to resolve disputes including disputes between husband and wife through deliberation to reach consensus a decision. An example is the Batak tribe solving problems through "Runggun adat forum", the Minang tribe uses the "peace judge institution" and Javanese tribes use "village consultation". Islam also provides opportunities for its adherents to resolve disputes in a friendly manner through an intermediary for other people neutral and impartial.

Mediation is the pattern chosen to resolve disputes between husband and wife This is regulated as stated in the Regulation of the Supreme Court Number 1 Year 2016 Article 1 Number 1 and Act No. 30 of 1999 Article 6 Paragraph (3) Inclusion of mediation as an alternative dispute resolution method in Act No.30 of 1999 it is hoped that it can become one a way of dispute resolution that has a positive impact on the parties and has the value of justice for all parties at the same time can prevent dispute resolution through court channels.

Settlement of disputes by Mediation is conflict resolution efforts by involving a neutral, unauthorized third party take decisions that help the disputing parties achieve settlement (solution) accepted by both parties. This type of mediation as we all know that there is mediation that is governed by Act No.30 of 1999 concerning Arbitration and alternative dispute resolution and mediation which is regulated by Supreme Court Regulation No.1 of 2008. Mediation as stipulated by Act No.30 of 1999 is suitable for business dispute resolution, this mediation is carried out outside the Court with procedures as regulated in Article 6 of Act No. 30 of 1999, meanwhile mediation which is regulated by the Supreme Court Regulation No.1 of 2008 is compulsory mediation which must be carried out by the parties and mediated by the Judge before the proceedings at the degree.

14 Laurensius Arliman S, Peranan Metodologi Penelitian Hukum Di Dalam Perkembangan Ilmu Hukum di Indonesia, Soumatera Law Review, Vol 1, No 1, 2018, page.112-132 
Article 2 paragraph (3) regulates the imposition of sanctions for those who are not willing go through the mediation process first before their case goes into process violation of the provisions of Article $130 \mathrm{HIR}$ and/or Article $154 \mathrm{RBg}$ resulting in the verdict being null and void, ${ }^{15}$ so this is an obligation must be done by the judge and approved by the parties. This mediation is a requirement that is included in the proceeding section Courts, both religious courts and district courts.

In the mediation process for husband and wife divorce cases it is hoped that it can suppress divorce rate, usually the judge as the mediator will provide advice marriage to the husband and wife and will also provide an overview of the risks maybe in the future if they have to divorce.

This mediation has no time limit, so if both parties are either husband or The wife feels that she still wants to abandon her intention to divorce, so the principle good faith must be put forward, still requesting the Judge to act as a mediator and hopes that he will provide advice before the Judge concludes the results agreement during the mediation process. The outcome of the agreement on the mediation process can be made in writing and signed by all parties. The mediator has a role important in the survival of someone who is facing a home this particular problem. Therefore, the mediator must also be embedded in his soul good faith to reconcile the two. The criteria for mediators ${ }^{16}$ there are:

a. The mediator has the ability to prepare everything related with problems that were left to him to solve.

b. The mediator must have sufficient knowledge of the problem at hand.

c. The mediator must have a clear and complete mind and is fast in that condition fast and uncertain.

d. Ability and skills to listen to complaints from parties.

e. Neutral

f. Be patient and can and quickly read the situation.

g. High integrity

h. As well as drawing conclusions in the form of a fair and reassuring decision both parties.

The mediator has a very important role as a mediator on a problem resolved through the mediation process, while the mediator functions in general are ${ }^{17}$ :

a. As a catalyst, which is shown by the ability to encourage its birth constructive atmosphere for dialogue or communication between the parties and not on the contrary, namely spreading misunderstanding and polarization between the party.

15 Devanry Tamalawe, The Effectiveness Of Mediation As Part Of A Form Of Divorce Prevention According To Law Civil Program, lex Crimen vol.V/No.3/Mar/2016, page. 22

16 DYWitanto, Procedure for Mediation in civil cases within the general court and religious courts according to Perma No. 1 of 2008 concerning mediation procedures in court, Alfabeta, Bandung

17 Prof. Dr. Takdir Rahmadi, Devanry Tamalawe, Lex Crimen, Vol. V/No.3/Mar/2016, page. 14-15 
b. As an educator, namely trying to understand the will, appreciation, work procedures, political limitations and business constraints of the parties.

c. As a translator, namely the mediator must try to convey and formulate suggestions from one party to the other through language or expressions which is nice to hear by other parties but without prejudice to the intent and target to be accomplished.

d. As a resource person, the mediator is expected to be able to utilize or multiply the usefulness of available information sources.

e. As the bearer of Bad News, the mediator must be aware of the parties in the negotiation process can be emotional, then the mediator must be ready accept unfavorable and harsh words and expressions from one party.

f. As a reality agent, namely the mediator who informs or provides understanding bluntly to one or the parties, that the target is impossible or it makes no sense to be achieved through the negotiation process.

g. As the scapegoat, the mediator must be prepared to be the party to be blamed when the people being mediated are not completely satisfied with terms and agreements.

Listening to some of the functions of the mediator, it can be considered something that is very important the role of the mediator to be able to help resolve it husband and wife problems, it takes a long time if you want peace for both both parties. Based on the theory of effectiveness as put forward by Soejono Soekanto ${ }^{18}$ that effectiveness is a success in achieving targets or goals that have been set. The effectiveness or not of a law is supported by 5 factors, namely legal factors, law enforcement factors, supporting facilities or facilities, community factors and factors culture By using this medium of mediation is considered effective to resolve husband and wife problem because the legal umbrella for conducting the mediation process has been provided by the Government with the Regulation of the Supreme Court No. 1 of 2016 Article 1 Number 1, Mediators in this case as law enforcers have also been provided by government. ${ }^{19}$ Due to the mediation process by the Court is a prior obligation enhanced to the realm of litigation, the community, in this case the husband and wife who are problematic and as users of the media in the Court, they will of course follow every procedure which is required.

\section{Barriers and Challenges of Mediation as an Option to Lower Numbers Divorce.}

Some of the advantages shown by mediation as an option by the parties, namely husband and wife to solve the problems they face is a

18https://knowledgeisfreee.blogspot.com/2015/10/pengentuk-penegakan-hukumkedasaran,html, on Alvi's thesis Syahri 2020, page. 22

19 Can act as a meditor is a judge, both a judge at the district court and a judge at the court religion. 
manifestation, the fourth and fifth precepts of Pancasila. The fourth precept reads: The populist in led by the wisdom of wisdom in deliberation/representation.

The 5th precept reads: Social justice for all the people of Indonesia

The content of the 4th and 5th precepts of Pancasila shows that each problems that occur in our country Indonesia always puts forward to finish using the peace process, deliberately hoping find common ground, so that justice will be achieved for both parties.

In cases of husband and wife divorce with mediation, it is hoped that the numbers will be pressed divorce, usually the judge as the mediator will provide advice marriage to the husband and wife and will also provide an overview of the risks maybe in the future if they have to divorce.

Lack of facilities and representative places to hold the mediation process at consider it as one of the obstacles in the implementation of this mediation, so that all parties feel uncomfortable and this results in the failure of the mediator to take it the right decision. Besides the reason for media facilities to carry out the mediation process In general, the parties have been provoked by emotions not to want to be reconciled assume that mediation is just a medium to buy time for a divorce is ingrained in their minds and has no permanent legal power to carry out what is the decision of the mediation, so that the media ion process in consider it just a formality and fail so that the divorce agenda continues to the litigation process.

The five factors that influence effectiveness in the mediation process are as follows already mentioned above such as the regulation of mediation itself, the enforcement factor legally, factors of supporting facilities or facilities, community factors and factors culture must be fulfilled all. If one is not fulfilled that results obstruction of the goals to be achieved by the main objective in holding the process mediation. The mediation pattern expects the resolution of a husband and wife problem want to divorce for some reason, if both are faced with the situation that is less conducive at the time the mediation process is held, it will affect the results of the mediation. The principles of good faith and sincerity of each party, both from the married couple who are going to divorce or from the mediator as well includes the atmosphere of the mediation process being carried out, in addition to the five elements of effectiveness in the mediation process must be fulfilled.

The decisions made by the mediator during the mediation process are powerless binding law, meaning that after the verdict is taken by the mediator above agreement between the two parties and set forth in black and white writing seta is signed by them including the mediator, it does not close possibility for either party to ignore what becomes their obligations. The nature of the verdict that is still floating is also a trigger for error one reason for the ineffectiveness of the mediation process for couples wishing to divorce. So that they hope that the mediation process 
will end soon and then continue with the process the trial with the final legacy.

As a challenge in the future, the mediation pattern that is required to be held before an event the problem goes into the realm of litigation as mandated by a Mighty Court Regulation no.1 of 2016, the Government needs to prepare facilities as well infrastructure representative for holding the mediation process, both mediator and the husband and wife must have good intentions to settle in a family manner.

\section{CONCLUSION}

Mediation as the pattern chosen for resolving disputes between husbands and This wife is an obligation that must be lived before their case examined in the realm of litigation as regulated in the Supreme Court Regulation Number 1 of 2016 Article 1 Number 1 . Settlement of disputes by Mediation is conflict resolution efforts involving neutral third parties, which are not has the authority to make decisions that help the parties who are the dispute reaches a resolution (solution) that is accepted by both parties. Some of the advantages indicated by mediation as an option by the parties namely husband and wife to solve the problems they face are as embodiment of the 4th and 5th precepts of Pancasila. Barriers and challenges to mediation as an option to reduce the divorce rate based on the theory of effectiveness still not showing its effectiveness, because of the fifth elements of effectiveness theory according to Soejono Soekanto must be fulfilled. The five elements these are regulatory/legal factors, law enforcement factors, facility factors, community factors and cultural factors. The four factors other than the facility factor can be fulfilled. The facilities referred to here are representative places conducting a mediation process and the spiritual atmosphere of the couple must be able to built by law enforcement and judicial institutions.

\section{Books :}

\section{BIBLIOGRAPHY}

Frans Hendra Winata, 2012, Indonesian and International National Arbitration Dispute Resolution Law, Second Edition, Sinar Grafika, Jakarta;

DYWitanto, Mediation Procedure Law in civil cases within the general courts and religious courts according to Perma No. 1 of 2008 on mediation procedures in court, Alfabeta, Bandung;

Endrik Safudin, 2018, Alternative Dispute Resolution and Arbitration, Intans Publishing, Malang;

Gary Goodpaster, 1999, Basic Economic Law Series 9: Guidelines for Negotiation and Mediation, translated Nogar Simanjuntak, Project ELIPS, Jakarta; 
Rudiyanti Dorotea Tobing, 2015, Aspects of Business Law: Definition, Principles, Theory and Practice, LaksBang Justitia, Surabaya

\section{Journals:}

Devanry Tamalawe, The Effectiveness of Mediation As Part Of A Form Of Divorce Prevention According To Procedural Law Perdata, lex Crimen, Vol.V/No.3/Mar/2016

Rika Lestari, Comparative Law of Dispute Resolution by Mediation at Courts and Outside Courts , Journal of Law Science, Volume 3 No. 2, 2013;

\section{Regulations:}

Pancasila

Constitution of 1945 Republic Indonesia

Act No. 30 of 1999 concerning Arbitration and Alternative Dispute Resolution

Supreme Court Regulation No.1 of 2016

\section{Other}

Al-Qur'an

Recap/report on the divorce rate of the Semarang City Religious Court for 20172019 